\title{
EFFECTS OF SOIL PROPERTIES ON COPPER SPECIATION IN SOIL SOLUTION
}

\author{
Beata Rutkowska, Wiesław Szulc, Karolina Bomze \\ Agricultural Chemistry Department \\ Warsaw University of Life Sciences-SGGW
}

\begin{abstract}
The numerical speciation analysis relies on quantitative assessment of concentrations of different forms of an element in soil solution (free ions, complex ions, neutral complexes), which have different abilities to react (ion activity). The reactivity affects the element's mobility and bioavailability. This method can be employed to estimate potential bioavailability and toxicity of a given element. This study was undertaken to evaluaate effects of selected soil properties on changes in the total concentration of copper $(\mathrm{Cu})$ and percentages of particular forms of this element in soil solution.

The study was based on a microplot experiment. The investigated factors were the soil texture, $\mathrm{pH}$, organic carbon content and degree of soil copper contamination. Soil solutions were obtained with the vacuum displacement method. The concentration of copper in soil solution was determined with the ICP method, and the percentages of particular copper forms in the total copper concentration were calculated with the MINTEQA 2 software. It was found that copper in the analysed soil solutions occurred mainly in the form of metalorganic complexes. The increasing soil acidity was correlated with an increased percentage of free copper ions and copper complexes with organic matter. Simultaneously, the share of bonds with carbonates, sulfates and hydroxyl groups decreased. A decrease in the percentage of $\mathrm{Cu}^{2+}$ free ions in the soil solution was observed in response to an increasing organic carbon content, while the percentage of copper complexes with organic matter rose. The degree of soil copper contamination and soil texture had no influence on the percentages of different copper forms in the soil solution.
\end{abstract}

Key words: soil solution, copper, soil properties, numerical speciation, MINTEQA.

dr hab. Beata Rutkowska prof. nadzw., Agricultural Chemistry Department, Warsaw University of Life Sciences-SGGW, Nowoursynowska 159, 02-776 Warsaw, e-mail: beata_rutkowska@sggw.pl 


\title{
WPŁYW WŁAŚCIWOŚCI GLEBY NA SPECJACJĘ MIEDZI W ROZTWORZE GLEBOWYM
}

\begin{abstract}
Abstrakt
Numeryczna analiza specjacyjna polega na ilościowej ocenie stężenia różnych form badanego pierwiastka w roztworze glebowym (wolne jony, jony kompleksowe, obojętne kompleksy), które charakteryzują się różną zdolnością do reagowania (aktywnościa jonów), co wpływa na ich ruchliwość i biodostępność. Metoda ta może więc być narzędziem umożliwiającym prognozowanie ich potencjalnej biodostępności lub toksyczności dla organizmów. $\mathrm{W}$ związku z tym podjęto badania dotyczące oceny wpływu wybranych właściwości gleby na zmiany całkowitego stężenia $\mathrm{Cu}$ oraz udziału poszczególnych form tego pierwiastka w roztworze glebowym.

W doświadczeniu mikropoletkowym badanymi czynnikami były skład granulometryczny, $\mathrm{pH}$, zawartość Corg. w glebie oraz stopień zanieczyszczenia gleby miedzią. Roztwór glebowy pozyskiwano metoda podciśnieniowa. Stężenie miedzi w roztworze glebowym oznaczono metodą ICP, a udział poszczególnych form miedzi w całkowitym stężeniu tego pierwiastka $\mathrm{w}$ roztworze glebowym obliczono za pomoca programu komputerowego MINTEQA 2. Stwierdzono, że w analizowanych roztworach glebowych miedź występuje głównie w formie kompleksów metaloorganicznych. Wraz ze wzrostem zakwaszenia zwiększał się w roztworze glebowym udział wolnych jonów i kompleksów miedzi z materią organiczną, a zmniejszał udział połączeń z węglanami, siarczanami i grupami hydroksylowymi. Wraz ze wzrostem zawartości C-org. w glebie, zmniejszał się w roztworze glebowym udział wolnych jonów $\mathrm{Cu}^{2+}$, a zwiększał udział kompleksów miedzi z materią organiczną. Stopień zanieczyszczenia gleby metalami ciężkimi i skład granulometryczny nie wpływały na procentowy udział różnych form miedzi w roztworze glebowym.
\end{abstract}

Słowa kluczowe: roztwór glebowy, miedź, właściwości gleby, specjacja numeryczna, MINTEQA.

\section{INTRODUCTION}

The chemical composition of soil solution can be exploited to predict both bioavailability of trace elements to plants as well as potential contamination of plants grown for feed or food (HiRsh, BANIN 1990, KHOSHGOFTAR et al. 2004). Considering the number and diversity of chemical forms of trace elements in soil solution, special attention should be paid to the method of numerical speciation analysis. The method is based on quantifying concentrations of various forms of a given element in soil solution in an attempt to calculate its bioavailability or toxicity to living organisms (PARKER, PEDLER 1986, CheCKAi et al. 1987, MinNich et al. 1987, CANCÉs et al. 2003).

The aim of the study was to determine the total concentration of copper $(\mathrm{Cu})$ an percentages of individual chemical forms of this element in soil solution depending on such soil properties as the soil grain size composition, soil reaction, organic carbon content and degree of soil copper contamination. 


\section{MATERIAL AND METHODS}

The study was based on a microplot experiment run at the Experimental Station of Agriculture, the Faculty of Biology at Warsaw University of Life Sciences in Skierniewice (central Poland). The microplots were represented by stoneware pots ( $1.2 \mathrm{~m}$ deep and $40 \mathrm{~cm}$ wide), which were filled with soil and placed outdoors.

The experimental factors were:

- three levels of soil $\mathrm{pH}: 4,5$ and 6 ;

- two soils: loamy sand (7\% clay, $6 \%$ silt, $87 \%$ sand), sandy loam (13\% clay, $5 \%$ silt, $82 \%$ sand);

- three levels of the content of soil organic carbon: 6, 9 and $12 \mathrm{~g} \mathrm{C} \mathrm{kg}^{-1}$;

- four degrees of soil contamination with $\mathrm{Cu}$ : natural content - $0\left(10 \mathrm{mg} \mathrm{kg}^{-1}\right)$, I (30 mg kg-1), II (50 mg kg-1) and III ( $80 \mathrm{mg} \mathrm{kg}^{-1}$ ) (KABATA-PendiAS et al. 1993).

The experiment consisted of 216 microplots, which represented 72 combinations of the investigated factors. All the factors were observed in three replications arranged in a split-plot experimental design. The experimental samples were collected from each microplot's topmost soil layer $(0-30 \mathrm{~cm}$ down). The soil samples were dried up to the level of air humidity. Afterwards, they were ground in a china mortar and put through a sieve with the $1 \mathrm{~mm}$ diameter mesh net. The samples thus prepared were used to obtain soil solutions according to the vacuum displacement method with a vacuum pump (Dynavac OP4). The total concentration of copper was determined by Inductively Coupled Plasma Atomic Emission Spectrometry (ICPAES method) (apparatus: IRYS Advantage ThermoElementar). The MINTEQA2 for Windows software was used for calculations of shares of particular forms of $\mathrm{Cu}$ ions in soil solution. The results were statistically analyzed with ANOVA and simple linear regression. The differences between means were analysed with the Tukey's test at $p=0.05$. Statistical analyses were conducted with Statgraphics 5.1. software.

\section{RESEARCH RESULTS}

The total concentration of $\mathrm{Cu}$ in the analysed soil solutions ranged from 1.23 to $2.25 \mu \mathrm{mol} \mathrm{dm}{ }^{-3}$ and differed depending on soil properties.

The results of ANOVA showed that the total concentration of copper in soil solutions increased significantly as the soil reaction became more acidic and the degree of copper soil contamination increased. The concentration of $\mathrm{Cu}$ was higher in soil solution of loamy sand than of sandy loam. The content of organic carbon did not significantly affect $\mathrm{Cu}$ concentrations in soil solution (Table 1). 
Total $\mathrm{Cu}$ concentration $\left(\mu \mathrm{mol} \mathrm{dm}^{-3}\right)$ versus soil properties

\begin{tabular}{|l|c|c|c|c|c|c|c|c|c|c|c|c|}
\hline \multirow{2}{*}{ Item } & \multicolumn{2}{|c|}{ Soil texture } & \multicolumn{3}{c|}{$\begin{array}{c}\text { Soil reaction } \\
\left(\mathrm{pH}_{\mathrm{KCl}}\right)\end{array}$} & \multicolumn{2}{c|}{$\begin{array}{c}\text { Content of organic } \\
\text { carbon }\left(\mathrm{g} \mathrm{kg}{ }^{-1}\right)\end{array}$} & \multicolumn{4}{c|}{$\begin{array}{c}\text { Degree of Cu soil } \\
\text { contamination }\end{array}$} \\
\cline { 2 - 13 } & $\begin{array}{c}\text { loamy } \\
\text { sand }\end{array}$ & $\begin{array}{c}\text { sandy } \\
\text { loam }\end{array}$ & 4 & 5 & 6 & 6.0 & 9.0 & 12.0 & 0 & I & II & III \\
\hline $\mathrm{Cu}$ & 1.76 & 1.26 & 2.05 & 1.46 & 1.38 & 1.52 & 1.52 & 1.49 & 1.23 & 1.31 & 1.75 & 2.25 \\
\hline $\mathrm{LSD}_{0.05}$ & \multicolumn{2}{|c|}{0.18} & \multicolumn{3}{c|}{0.21} & \multicolumn{3}{c|}{0.27} & \multicolumn{5}{c|}{0.25} \\
\hline
\end{tabular}

The results of speciation analysis of copper in soil solutions indicated the highest percentage of $\mathrm{Cu}$ complexes with organic matter and carbonates. The prevalent forms of copper were Cu-org. complexes, whose average share ranged from 28.2 to $93.2 \%$ of the total concentration of copper in soil solution. The second most abundant form of copper observed in soil solutions were $\mathrm{Cu}-\mathrm{CO}_{3}$ complexes, whose contribution to total copper ranged from 12.7 to $62.3 \%$, depending on soil properties (Tables $2-5$ ).

Table 2

Percentages of different copper forms in soil solution according to soil $\mathrm{pH}$ value $\left(\mathrm{pH}_{\mathrm{KCl}}\right)$

\begin{tabular}{|l|c|c|c|}
\hline \multirow{2}{*}{ Form of $\mathrm{Cu}$} & \multicolumn{3}{|c|}{ Soil $\mathrm{pH}$} \\
\cline { 2 - 4 } & 4.0 & 5.0 & 6.0 \\
\hline $\mathrm{Cu}^{2+}$ & 6.5 & 5.9 & 4.4 \\
\hline $\mathrm{Cu}-$-org. & 93.2 & 56.2 & 28.2 \\
\hline $\mathrm{CuOH}^{+}$ & tc* & 3.0 & 3.4 \\
\hline $\mathrm{Cu}-\mathrm{CO}_{3}$ & tc & 34.6 & 62.3 \\
\hline $\mathrm{Cu}\left(\mathrm{CO}_{3}\right)_{2}^{2-}$ & tc & tc & 1.4 \\
\hline
\end{tabular}

*trace content

The highest percentage $(93.2 \%)$ of Cu-org. complexes in the total concentration of copper was observed in the soil solutions of most acid soils (Table 2). As the soil $\mathrm{pH}$ was increasing, amounts of metalorganic complexes of copper were steadily decreasing, while the percentage of $\mathrm{Cu}-\mathrm{CO}_{3}$ complexes was growing. Copper complexes with carbonates reached $34.6 \%$ in the solutions of soils with $\mathrm{pH} 5.0$ and $62.3 \%$ in the solutions of soils with $\mathrm{pH}$ 6.0. Other forms of copper $\left(\mathrm{CuOH}^{+}, \mathrm{Cu}-\mathrm{CO}_{3}\right.$ and $\left.\mathrm{Cu}\left(\mathrm{CO}_{3}\right)_{2}{ }^{2-}\right)$ were not observed in the solutions of soils with the lowest $\mathrm{pH}$ value. At the same time, their share in the total $\mathrm{Cu}$ concentration in solutions of soils with higher $\mathrm{pH}$ was relatively low (Table 2). 
Regardless of the degree of soil $\mathrm{Cu}$ contamination, the dominant forms of copper in soil solution were $\mathrm{Cu}$-org. complexes, which approximately made up 59\% of this element's total soil solution concentration. At the same time, a relatively high percentage $(32 \%)$ of $\mathrm{Cu}-\mathrm{CO}_{3}$ complexes was observed. In both $\mathrm{Cu}$ unpolluted and contaminated soils, an average share of free ions $\mathrm{Cu}^{2+}$ was just $5.5 \%$ of the total concentration of copper in soil solution (Table 3).

Table 3

Percentages of different copper forms in soil solutions according to soil copper contamination

\begin{tabular}{|l|c|c|c|c|}
\hline \multirow{2}{*}{ Form of $\mathrm{Cu}$} & \multicolumn{4}{|c|}{ Degree of Cu soil contamination } \\
\cline { 2 - 5 } & 0 & I & II & III \\
\hline $\mathrm{Cu}^{2+}$ & 5.4 & 5.4 & 5.7 & 5.8 \\
\hline $\mathrm{Cu}-$ org. & 59.4 & 58.6 & 59.0 & 59.8 \\
\hline $\mathrm{CuOH}$ & 2.1 & 2.1 & 2.2 & 2.1 \\
\hline $\mathrm{Cu}-\mathrm{CO}_{3}$ & 33.0 & 33.0 & 32.3 & 31.6 \\
\hline $\mathrm{Cu}\left(\mathrm{CO}_{3}\right)_{2}^{2-}$ & 0.5 & 0.5 & 0.5 & 0.5 \\
\hline
\end{tabular}

Table 4

Percentages of different copper forms in soil solution according to content of soil organic carbon

\begin{tabular}{|l|c|c|c|}
\hline \multirow{2}{*}{ Form of $\mathrm{Cu}$} & \multicolumn{3}{|c|}{ Content of soil organic carbon $\left(\mathrm{g} \mathrm{kg}^{-1}\right)$} \\
\cline { 2 - 4 } & 6.0 & 9.0 & 12.0 \\
\hline $\mathrm{Cu}^{2+}$ & 6.5 & 5.3 & 5.0 \\
\hline $\mathrm{Cu}$-org. & 37.1 & 61.7 & 78.8 \\
\hline $\mathrm{CuOH}^{+}$ & 2.6 & 2.1 & 1.8 \\
\hline $\mathrm{Cu}-\mathrm{CO}_{3}$ & 52.6 & 30.1 & 14.2 \\
\hline $\mathrm{Cu}\left(\mathrm{CO}_{3}\right)_{2}^{2-}$ & 0.9 & 0.5 & - \\
\hline
\end{tabular}

The effect of the content of soil organic carbon on copper speciation in soil solutions was considerable. A two-fold increase of soil organic carbon content nearly doubled the share of $\mathrm{Cu}$-org. in the total concentration of copper in soil solution (from $37.1 \%$ to $78.8 \%$ ). Simultaneously, the percentage of $\mathrm{Cu}-\mathrm{CO}_{3}$ complexes decreased three-fold (from $52.6 \%$ to $14.2 \%$ ). Free ions $\mathrm{Cu}^{2+}$ made up 5.0\% of all $\mathrm{Cu}$ forms in soil solutions of the soils characterized by the highest content of organic carbon, and $6.5 \%$ in soil solution of soils with the lowest content of organic carbon. Other forms of copper represented low percentages in the total content of copper in the soil solution (Table 4). 
Soil texture had a weak effect on the share of copper forms in the distribution of this element in soil solution. The Cu-org. form was prevalent in the solutions of all the analysed soils: an average share of this form in the total copper concentration in soil solutions was $56.7 \%$ in sandy loam soil and $60.8 \%$ in loamy sand. The $\mathrm{Cu}-\mathrm{CO}_{3}$ complexes had a large share in the overall distribution of copper forms in soil solutions. Unlike $\mathrm{Cu}$-org., they were more abundant in sandy loam soil solutions (on average $34.5 \%$ ). In loamy sand soils, complexes of copper with carbonates constituted $30.0 \%$ of the total amount of copper in the soil solution (Table 5).

Table 5

Percentages of different copper forms according to soil texture

\begin{tabular}{|l|c|c|}
\hline \multirow{2}{*}{ Form of $\mathrm{Cu}$} & \multicolumn{2}{|c|}{ Soil texture } \\
\cline { 2 - 3 } & loamy sand & sandy loam \\
\hline $\mathrm{Cu}^{2+}$ & 5.8 & 5.6 \\
\hline $\mathrm{Cu}$-org. & 60.8 & 56.7 \\
\hline $\mathrm{CuOH}^{+}$ & 2.9 & 2.3 \\
\hline $\mathrm{Cu}-\mathrm{CO}_{3}$ & 30.0 & 34.5 \\
\hline $\mathrm{Cu}\left(\mathrm{CO}_{3}\right)_{2}{ }^{2-}$ & 0.5 & 0.5 \\
\hline
\end{tabular}

\section{DISCUSSION}

The results of the present study suggest a significant effect of soil properties on the total concentration of copper in soil solution. In solutions of the analysed soils, total copper concentrations increased due to soil $\mathrm{Cu}$ contamination and in response to soil acidification. At the same time, the copper total concentration was higher in solution of loamy sand soil. On the other hand, no effect of the soil organic carbon content on the total concentration of $\mathrm{Cu}$ in soil solution was observed (Table 1). Such influence of soil properties on copper concentration in soil solution has been confirmed by other authors (JefFery, UREn 1983, McGrath et al. 1988, SAuvÉ et al. 1997). The observed effects are attributed to the high affinity of copper for organic matter (NORVELL 1991).

The observed high ratio of $\mathrm{Cu}$-org. complexes in the total concentration of copper in soil solution is confirmed in literature (SANDERS 1982, 1983, MCBRIDE, Bouldin 1984, Fotovat, Naidu 1997). The share of metalorganic complexes estimated in this experiment at 28.2 to $93.2 \%$ corresponds well with the results of SMAL (1999), which were obtained with the use of SOILCHEM 
software. The latter showed that copper organic complexes amounted to $75.4 \%$ of the total concentration of this element in soil solution of a humus layer of forest soils and $48.4 \%$ in agricultural soils. The results of the numerical analysis of organic soil solutions carried out by RUTKowskA (2008) with the MINTEQA2 software indicated that the percentage share of $\mathrm{Cu}$ org. complexes in the total concentration of copper in soil solution ranged from 74 to $86 \%$. Even a higher percentage of copper organic complexes, reaching 99.5\%, was found by McBRIDE and BouLDIN (1984).

In the analysed solutions, copper was also found in the form of complexes with carbonates, whose share ranged from 12.7 to $62.3 \%$ of the total concentration of copper in soil solution, depending on soil reaction and soil richness in organic carbon (Tables 2-5). The share of $\mathrm{Cu}-\mathrm{CO}_{3}$ complexes in soil solution decreased with an increase of soil organic carbon content and a change of soil reaction into acid one. SMAL (1999), SAEKI et al. (2002) and RUTKOWSKA (2008) confirmed presence of copper in the form of $\mathrm{Cu}-\mathrm{CO}_{3}$ complexes in soil solution. However, none of these authors obtained a percentage of this form in soil solution as high as observed in the present study. RUTKOWSKA (2008) showed that solutions of agricultural soils contain complexes of copper with carbonates on a level ranging from 5.0 to $6.8 \%$ of the total concentration of $\mathrm{Cu}$ in soil solution.

Regardless of the soil properties investigated, a small percentage of free $\mathrm{Cu}^{2+}$ ions was observed in the total concentration of copper in soil solution. Similar observations were reported by NoLAN et al. (2003) who showed a 5\% share of free $\mathrm{Cu}^{2+}$ ions in the soil solutions analysed in their research. A small share of free $\mathrm{Cu}^{2+}$ in soil solution, no more than slightly over $12 \%$, was also observed by SANDERs (1983), McGrath et al. (1988) and Fotovat, NAIDU (1997). According to Yuan (2009), Wóscikowska-Kapusta, Niemczuk (2009) and JaWORSKa, DĄBKowsKa-NASKREtT (2012) this result is due to the strong binding of copper by the soil solid phase. As claimed by CANCÉS et al. (2003), speciation of copper in soil solution is conditioned by soluble forms of organic substance. SAlam, Helmke (1998) suggest that complexing is a reaction that substantially conditions the course of copper speciation in soil solution.

According to Smal (1999), SAeKr et al. (2002), ARtiola (2005) and RUtKowsKa (2008) copper in soil solution can also form bonds with other nonorganic ligands (e.g. $\mathrm{SO}_{4}{ }^{2-}, \mathrm{NH}_{3}, \mathrm{NO}_{3}^{-}, \mathrm{H}_{2} \mathrm{PO}_{4}{ }^{2-}, \mathrm{Cl}^{-}, \mathrm{OH}^{-}$). In the numerical speciation analysis carried out in this study, a small proportion of $\mathrm{CuOH}^{+}$bonds was detected in the analysed soil solutions, but other forms were not observed (Tables 2-5). 


\section{CONCLUSIONS}

Based on the numerical speciation analysis of copper in the solutions of soils with different physical and chemical properties it was concluded that:

- the estimates derived by running a MINTEQA2 software package of the percentages of ion forms in soil solutions showed that copper occurred in soil solution in the form of complexes with humus acids;

- among the soil properties studied, soil reaction had the strongest influence on the per cent shares of copper forms in soil solution; in a more acid soil, the ratio of copper free ions and copper complexes with organic matter, bonds with carbonates as well as sulfates and hydroxyl groups decreased;

- the degree of soil $\mathrm{Cu}$ contamination and soil texture had no effect on percentages of different forms of copper in soil solution;

- with a higher organic carbon content in soil, soil solution contained a lower share of free copper ions, whereas the share of copper complexes with organic matter increased.

\section{REFERENCES}

ARTiola J.F. 2005. Speciation of copper. In: Handbook of elemental speciation II. Species in the environment, food, medicine and occupational health. Cornelis R. Caruso J., Crews H., Heumann K. (eds). John Wiley\&Sons Ltd., England, 174-187.

Cancés B., Ponthieu M., Castrec-Pouelle M., Aubry E., Benedetti M.F. 2003. Metal ions speciation in a soil and its soil solution: experimental data and model results. Geoderma, 113: 341-355.

Checkai R.T., Hendrickson L.L., Corey R.B., Helmke P.A. 1987. A method for controlling the activities of free metal, hydrogen and phosphate ions in hydroponic solution using ion exchange and chelating resins. Plant Soil, 99: 321-334.

Fotovat A., NaIDU R. 1997. Ion exchange resin and MINTEQA2 speciation of $\mathrm{Zn}$ and $\mathrm{Cu}$ alkaline sodic and sodic extracts. Aust. J. Soil Res., 35: 711-726.

Hirsh D., Banin A. 1990. Cadmium speciation in soil solution. J. Environ. Qual., 19: 366-372.

JAWORSKA H., DABKowSKA-NASKRĘT H. 2012. Influence of the Gtogów copper works on the content of mobile forms of copper and zinc in arable soils. J. Elem., 17(1): 57-66.

JEFFERY J.J., UREN N.C. 1983. Copper and zinc species in the soil solution and the effects of soil pH. Aust. J. Soil Res., 21: 479-488.

Kabata-Pendias A., Motowicka-Terelak T., Piotrowska M. 1993. Assessment of the degree of contamination of soils and plants by heavy metals and sulfur. Wyd. IUNG, Puławy, 1-20. (in Polish)

Khoshgoftar A.H., Shariatmadari H., Karimian N., Kalbasi M., Van der Zee S.E.A.T.M., Parker D.R. 2004. Salinity and zinc application effects on phytoavailability of cadmium and zinc. Soil Sc. Am. J., 68: 1885-1889.

McBRide M.B., Bouldin D.R. 1984. Long-term reactions of copper (II) in a contaminated calcareous soil. Soil Sci. Soc. Am. J., 48: 56-59.

McGrath S.P., Sanders J.R., Shalaby M.H. 1988. The effects of soil organic matter levels on soil solution concentrations and extractabilities of manganese, zinc and copper. Geoderma, 42: 177-188. 
Minnich M.M., McBride M.B., Chaney R.L. 1987. Copper activity in soil solution: II. Relation to copper accumulation in young snapbeans. Soil Sci. Soc. Am. J., 51(3): 573-578.

Nolan A.L., McLaughuin M.J., Mason S.D. 2003. Chemical speciation of $\mathrm{Zn}, \mathrm{Cd}, \mathrm{Cu}$, and $\mathrm{Pb}$ in Pore Waters Agricultural and Contaminated Soils Using Donnan Dialysis. Environ. Sci. Technol., 37: 90-98.

Norvell W.A. 1991. Reactions of metal chelates in soils and nutrient solutions. In: Micronutrients in agriculture. $2^{\text {nd }}$ Edn. (eds. Mortvedt J.J., Cox F.R., Shuman L.M., Welch R.M.) Soil Science Society of America, Madison, 187-227.

Parker D.R., Pedler J.F. 1996. Reevaluation of the free-ion activity model of trace metal availability to higher plants. Plant Soil, 196: 223-228.

Rutкowska B. 2008. Determining the changeability of the chemical composition of organic soil solutions based on soil usage and conditioning. SGGW, Warszawa, 137 pp. (in Polish)

Saeki K., Kunito T., Oyaizu H., Matsumoto S. 2002. Relationship between bacterial tolerance levels and forms of copper and zinc in soils. J. Eviron. Qual., 31: 1570-1575.

Salam A.K., Helmke P.A. 1998. The $p H$ dependence of free ionic activities and total dissolved concentrations of copper and cadmium in soil solution. Geoderma, 83: 281-291.

SANDERS J.R. 1982. The effect of $p H$ on the copper and cupric ion concentration in soil solutions. J. Soil Sci., 33: 679-689.

SANDERS J.R. 1983. The effect of $p H$ on the total and free ionic concentrations of manganese, zinc and cobalt in soil solutions. J. Soil Sci., 34: 315-323.

Sauvé S., McBride M., Norvell W.A., Hendershot W. 1997. Copper solubility and speciation of in situ contaminated soils: effects of copper level, $p H$ and organic matter. Water Air Soil Poll., 100: 133-149.

Smal H. 1999. Soil solution chemistry of light textured soils and the effect of acidification on its changes. Rozpr. Nauk. AR Lublin, 230:108 pp. (in Polish)

Wójcikowska-Kapusta A., Niemczuk B. 2009. Copper speciation in different - type soil profiles. J. Elementol., 14(4): 815-824.

YUAN G. 2009. Copper, zinc and nickel in soil solution affected by biosolids amendment and soil management. Aust. J. Soil Res., 47: 305-310. 